\title{
Pictorial and Multimodal Metaphors in Informational Picture Books for Children -A Case Study
}

\author{
Wujuan Wang \\ School of Arts and Sciences, Shaanxi University of Science and Technology, Xi'an, China \\ Email: wangwujuan@sust.edu.cn
}

How to cite this paper: Wang, W. J. (2021). Pictorial and Multimodal Metaphors in Informational Picture Books for Children-A Case Study. Open Journal of Modern Linguistics, 11, 761-785.

https://doi.org/10.4236/ojml.2021.115060

Received: August 10, 2021

Accepted: September 19, 2021

Published: September 22, 2021

Copyright $\odot 2021$ by author(s) and Scientific Research Publishing Inc. This work is licensed under the Creative Commons Attribution International License (CC BY 4.0).

http://creativecommons.org/licenses/by/4.0/

\begin{abstract}
This article aims to explore how the use of pictorial and multimodal metaphors in informational picture books contributes to children's understanding of the information or facts and, at the same time, attracts their interest in the plot of the story. The sample picture book selected for the analysis is Inside the Human Body, from The Magic School Bus series, the informational picture books written by Joanna Cole and illustrated by Bruce Degen. Based on Forceville's categorization of pictorial and multimodal metaphors, the sample text is analyzed from three perspectives, namely, the construction of the narrative reality transmitted in this picture book, the identity construction of the main characters and the interaction of pictorial and multimodal metaphors in the successfully representation of the information to the young viewer in the book. The results of the analysis show that pictorial metaphors are employed in the construction of the narrative reality transmitted in the picture book to make the plot of the story interesting and reasonable; the picture book resorts to multimodal designs to construct the unique identities of its main characters both verbally and pictorially; the text writer and the illustrator of the information picture book collaborate to present the concepts and information through the combination of different types of pictorial and multimodal metaphors. The analysis also suggests that most of the pictorial metaphors are represented with two pictorially present terms (MP2) and verbo-pictorial metaphors (VPMs).
\end{abstract}

\section{Keywords}

Pictorial Metaphor, Multimodal Metaphor, Informational Picture Books, Inside the Human Body 


\section{Introduction}

Metaphor has long been studied as a mode of thought used to conceptualize reality by means of the relationships that are formed between a source domain and a target domain, since the theory has been introduced in two milestone publications: Metaphor and Thought (1979), edited by Andrew Ortony, and Metaphors we live by (1980), written by Lakoff and Johnson. With the development in cognitive metaphor theory, the Conceptual Metaphor Theory (CMT), initiated by Lakoff and Johnson, has been explored deeply and widely in many areas of study (Gibbs, 2008; Johnson, 1987, 1993, 2007; Lakoff, 1987, 1993; Turner, 1996). Among them, Gibbs's edited book The Cambridge Handbook of Metaphor and Thought was labeled as "the most comprehensive collection of essays in multidisciplinary metaphor", in which metaphor is claimed to play a fundamental role in education, mathematics, culture, literature, semantics, psychoanalysis, music and etc.

Further metaphor study leads many renowned linguists to the claim that metaphor structures thought and action; it is manifested not only through language, but also via other modes of communication as well, such as pictures, music, sound, gestures, videos, films and TV programs (Forceville, 1996; Forceville \& Urios-Aparisi, 2009; Kress, 2010). In Multimodal Metaphor edited by Forceville \& Urios-Aparisi (2009: p. 4), the focus of the collection of study is on multimodal metaphor, "metaphors whose target and source are rendered exclusively or predominantly in two different modes/modalities".

Forceville defines multimodal metaphor as a cognitive process in which "the target and the source domains of a metaphor are represented exclusively or predominantly in different modes" (Forceville, 2009b: p. 24). Through metaphor, one entity or concept can be mapped onto another phenomenon of a different conceptual domain. Visual tropes play a role as important as verbal metaphors, depending on the genre in which they are used (Forceville, 1996, 2009b). Case studies of verbal and pictorial metaphors in printed material in advertising (Forceville, 1996, 2002; Wiggin \& Miller, 2003; McQuarrie et al., 2008; Yu, 2009; Wang \& Wang, 2018), comics (Schilperoord \& Maes, 2009; Bounegru \& Forceville, 2011), political cartoons (El Refaie, 2003; Wang \& Xin, 2019; Ma \& Gao, 2020), picture books (Jesús Moya Guijarro, 2013; Zhao, 2017; Meng, 2019), and more modes like sound and music in the research of films and TV programs (Forceville, 1999; Whittock, 1990; Rohdin, 2009; Forceville, 2016) further verify the claim that identification and interpretation of the metaphors not only take place on the basis of the image and text, but also partially depend on the specific target (sub)group and (sub)cultural context (Forceville, 1996: pp. 108-163).

In the picture books for kids, metaphors are often employed to introduce new entities or abstract concepts to the young readers as their cognitive abilities are still developing. However, metaphors in children's picture books are not thoroughly and comprehensively studied, especially pictorial metaphors, as the target viewer of this genre is children under nine, who are not cognitively mature to understand the communicative potential of metaphorical constructions (Jesús 
Moya Guijarro, 2013). Nevertheless, chances are most picture books are written, edited and illustrated by adults who may be experts in using various tropes to satisfy their young readers.

In China's Dangdang Inc., a Chinese E-commerce company, 10 books among the top 20 bestsellers in children's books for the last three years are informational books (including picture books and encyclopedias for children). For three years in a row, two of the Magic School Bus series are on the top 5 of the best-selling books for children from 2018 to 2020, with each followed by millions of comments by viewers (see http://bang.dangdang.com/books/childrensbooks/01.41.00.00.00.00-year-2020-0 -1-1-bestsell). And in America, the series are labeled as "the best-selling science series ever". In a way, the best-selling list indicates that children are increasingly interested in information books. But taking their cognitive capability into account, how do the text writers and the illustrators convey some complicated information so that the children can understand the knowledge, facts and ideas represented?

This article aims to explore how the application of pictorial and multimodal metaphors (including similes, metonymies, personifications) in high-quality informational picture books for kids may contribute to children's understanding of the plot, knowledge, facts etc., and, in turn, arouse their interests in the story and information, or even the characters.

An internationally well-known picture book Inside the Human Body has been selected from its The Magic School Bus series as a sample text for the present study (Cole, 1990). As is the case with any informational picture book, the verbal messages and the illustrations are attached great importance in the construction of plot for the target viewers: children of $4-8$ years old (6 - 9 in some edition). The question arises as to what devices are used in the two modes to make the young readers both informed and amused, and how are these devices incorporated to fulfill the task. Taking Joanna's Inside the Human Body as a telling example, this paper intends to analyze the pictorial and multimodal metaphors employed in the identity construction of the character, the representation of the complicated and abstract information to children.

Therefore, the study will be focused on the following questions:

What types of metaphors are employed in the construction of narrative reality transmitted in the picture book? How do they contribute to the overall theme in the narrative?

How does the picture book construction the identity of the main characters?

How is the information presented in the picture book?

Which metaphors are most frequently employed in (informational picture books) Inside the Human Body?

\section{The Concept of Multimodal Metaphor}

Cognitive linguistics constructed Conceptual Metaphor Theory (CMT) mostly 
on verbal semiotics, having largely ignored nonverbal metaphors such as pictures, sounds, music, gestures, and other forms of expression (Forceville, 2008: p. 463). Through research and analysis, Gibbs (2008) explored the importance of various modes in the construction and representation of metaphors. These studies have led to a multimodal shift in metaphor research since the end of the 20th century. This shift began with the study of pictorial metaphors and gradually expanded to multimodal metaphors.

Forceville (1996) first studied pictorial metaphors from a conceptual perspective, using interaction theory to describe the composition and classification of pictorial metaphors. Later, metaphor studies were extended to new fields of study, nonverbal and multimodal metaphors were widely recognized and research models have been constructed. Researches, based on these models have been carried out thereafter, mostly focusing on case studies of different genres, for example, advertisements, comics, gestures, films and etc.

These studies tend to employ Forceville's source-and-target-domain mapping theory to elaborate and interpret multimodal metaphors, focusing on pictorial and multimodal metaphors, the similarities and differences between verbal and nonverbal metaphors, and the interaction between multimodal metaphor and verbal and visual tropes. The findings of these studies, including the pragmatic function of metaphors, the dynamic and narrative nature of multimodal metaphor, and the universality of the "concrete is concrete" mapping theory, have given rise to the systematic analysis of multimodal metaphors.

Multimodal metaphors are defined as "metaphors in which target, source, and/or mappable features are represented or suggested by at least two different sign systems (one of which may be language) or modes of perception" (Forceville, 2008: p. 463). Through his research, Forceville comes to the conclusion that pictorial and multimodal metaphors differ from verbal metaphors. Firstly, the pictorial or multimodal metaphors, with perceptual immediacy in pictures, sounds and gestures, are more easily apprehended. Second, pictorial and multimodal representations cue the similarity between target and source in a different way, depending on the medium employed. Third, pictorial and multimodal metaphors are accessible to more cross-cultural communities than verbal ones, as sounds and pictures speak a much more easily recognized universal language than languages. Lastly, it is likely that pictorial and multimodal source domains have a stronger emotional appeal than verbal ones (Forceville, 2008).

Forceville (1996: pp. 108-164) distinguished four types of pictorial metaphor in his study of pictorial metaphor in advertisements and billboards, namely, metaphors with one pictorially present term (MP1s), metaphors with two pictorially present terms (MP2s), pictorial similes, and verbo-pictorial metaphors (VPMs). Further study of metaphor in pictures and multimodal representations leads to the categorization of multimodal metaphors into four subtypes: contextual metaphors, hybrid metaphors, pictorial similes and verbo-pictorial metaphors, the same category as in pictorial metaphor (Forceville, 2008: pp. 464-469). 
The paper, based on the categorization of pictorial and multimodal metaphors proposed by Forceville $(1996,2008)$, intends to specify the pictorial and multimodal metaphors employed in Inside the Human Body, an informational picture book for children, with reference to cognitive psychology.

\section{The Significance of Informational Picture Books}

Curiosity is the nature of children. They are not only eager to learn about the world they can see and feel, but also the world beyond their limited experience and knowledge, which in turn stimulates their stronger curiosity. Informational picture books refer to books that combine texts and pictures to make up a story in an aesthetic manner and to impart knowledge, ideas or facts about the world in a truthful and reliable manner. High-quality picture books are expected to present information in a way that inspire children to think, question, feel, connect and wonder rather than simply acquire information or accept an explanation (https://pepelt21.com/informational-picturebooks/).

Given the developing cognitive condition of the target young audience, colorful drawings and simple language are employed to exhibit the information of science and nature. That cannot be so easy. Generally speaking, informational picture books appear in various genres, using different formats and media. The topics covered include various themes, like biographies, earthquake, outer space, insects or dinosaurs, and etc. Visual media including artwork, photos, maps are usually used to supplement the verbal messages, in different formats and layouts.

Based on Piaget's stages of children's cognitive development, Siltane (1986) divides children's metaphor comprehension into four developmental stages. In the first stage, children aged 3 - 5 years can understand simple metaphors based on their perception; In the second period, children of 6 - 8 years old can understand simple and moderately difficult metaphors based on multiple perceptions; in the third period, children of 9 - 11 years old not only have the ability to understand metaphors, but also to process metaphors themselves; in the fourth stage, at the age of 12 years, children can understand simple, moderately difficult, and difficult metaphors.

Seitz's (1997) study discovers that 4-year-old children show very good metaphoric understanding, and they are able to fulfill matching tasks between pictures and verbal texts based on their similarity. The finding leads to the conclusion that children of 4 not only understand pictorial metaphor and verbal metaphor, but also understand the interaction between them. In China, studies of children's metaphor cognition focus on its educational application (Dong, 2014).

However, a few studies of multimodal metaphor have focused on picture books so far. Wang (2013), through empirical research of 90 preschool children, researches into the children's cognitive ability in reading informational picture books. The study suggests that informational picture books are of great importance for preschool and primary children in their understanding of the world around them and beyond. Zhao Xiufeng, Li Xiaowei (2016) researched into pic- 
torial representations of ANGER in ten narrative picture books based on an EMOTION representation model of continuum from metonymy to metaphor and a system of pictorial and verbal representations from the perspective of cognitive poetics. The study indicates that pictorial metonymy and metaphors have more forceful cognitive impacts. The current article attempts to contribute to the research on pictorial metaphor and multimodal metaphor by exploring the importance of their representation and interaction in an informational picture book intended for children. The focus of the study resides essentially in researching how pictorial and multimodal metaphors contribute to representing the real-world information that the author and illustrator try to transmit to their young readers in the picture book, hoping to throw a little light into the construction of the genre.

\section{The Magic School Bus Series and Inside the Human Body}

The sample text Inside the Human Body, a picture book of the Magic School Bus series, is typically a high-quality informational picture book. Scholastic Inc classifies the series under the genre of "informational text" and "adventure", recommended to children of 4 to 8 years old, and the series have gained a world-wide reputation, a litany of awards in America, and have been one of the bestsellers in children's books for the last five years in a row in China's Dangdang Inc, a Chinese E-commerce company. The series are popular around the world mostly because it is so well written that makes science interesting and easy to understand for children. The series has 13 core titles and dozens more connected titles, and there are more than 93 million copies in print across 13 countries, according to Scholastic Inc (https://www.scholastic.com/aboutscholastic/). However, The Magic School Bus series have not been studied worldwide.

In Inside the Human Body, Ms. Frizzle, the science teacher, is taking her class to a museum to visit an educational exhibition on how the human body functions. Instead of making to the museum, the bus arrives at inside Arnold's body, as he swallows the bus carelessly. The students take a tour around Arnold's stomach, his intestines, his bloodstream, and more from the inside on the heart-stopping field trip and learn about how the organs inside human body normally work, not aware of the fact that they are inside Arnold's body.

In alignment with the stories and the pictures, the verbal texts in Inside the Human Body consist of four different formats. One is presented on the boards hanging on the wall, in the form of notebook pages and ink sketches, the exhibition of interesting scientific facts or discoveries collected by the students, closely related to the theme of the page; the second format is the narration in the voice of an unnamed student in Ms. Frizzle's class, telling the audience what is happening; the third is speech bubbles with the dialogues between the students and/or the teacher. And the last one is the dialogue between Arnold and a bird in his way back to school while the rest of the class stay inside his body. Different formats interact with one another, pushing the plot forward. 
The layout of the double spread is illustrated in Figure 1, a typical double spread in the book, which may include 3 columns, with the left column, taking up $1 / 6$ of the space, mostly devoted to some interesting facts or information shown in the board on the wall, the right column, taking up another $1 / 6$ of the space, depicting what is happening to Arnold, the student who misses the bus. And the middle column, usually taking up two thirds of the whole spread, is the major and predominant part of the book.

The article will first look into the narrative and plot of the story, trying to investigate into the metaphors employed. The identity constructions of main characters of the story are to be analyzed from multimodal perspective. After that, pictorial and multimodal metaphors in the picture book are to be explored with the integration model proposed by Forceiville $(1996,2008)$.

\section{The Analysis}

In this section, analyses will be carried out from three dimensions. First, the study will focus on the narration and plot of the story, to discuss the metaphors in the overall narratives; second, verbal and pictorial information will be dissected to explore the multimodal design of the identity construction of the main characters; thirdly, the pictorial and multimodal metaphors employed in the adventure inside the human body will be analyzed. Due to space restrictions, only a few double spread plates and illustrations have been reproduced here.

\subsection{Pictorial Metaphors in the Construction of the Narrative Reality Transmitted in the Picture Book}

Narrative is generally defined as the use of a written or spoken commentary to convey a story to the audience. The overall narrative structure of Inside the $\mathrm{Hu}$ man Body is compact and orderly, guiding the young viewer to tour around the

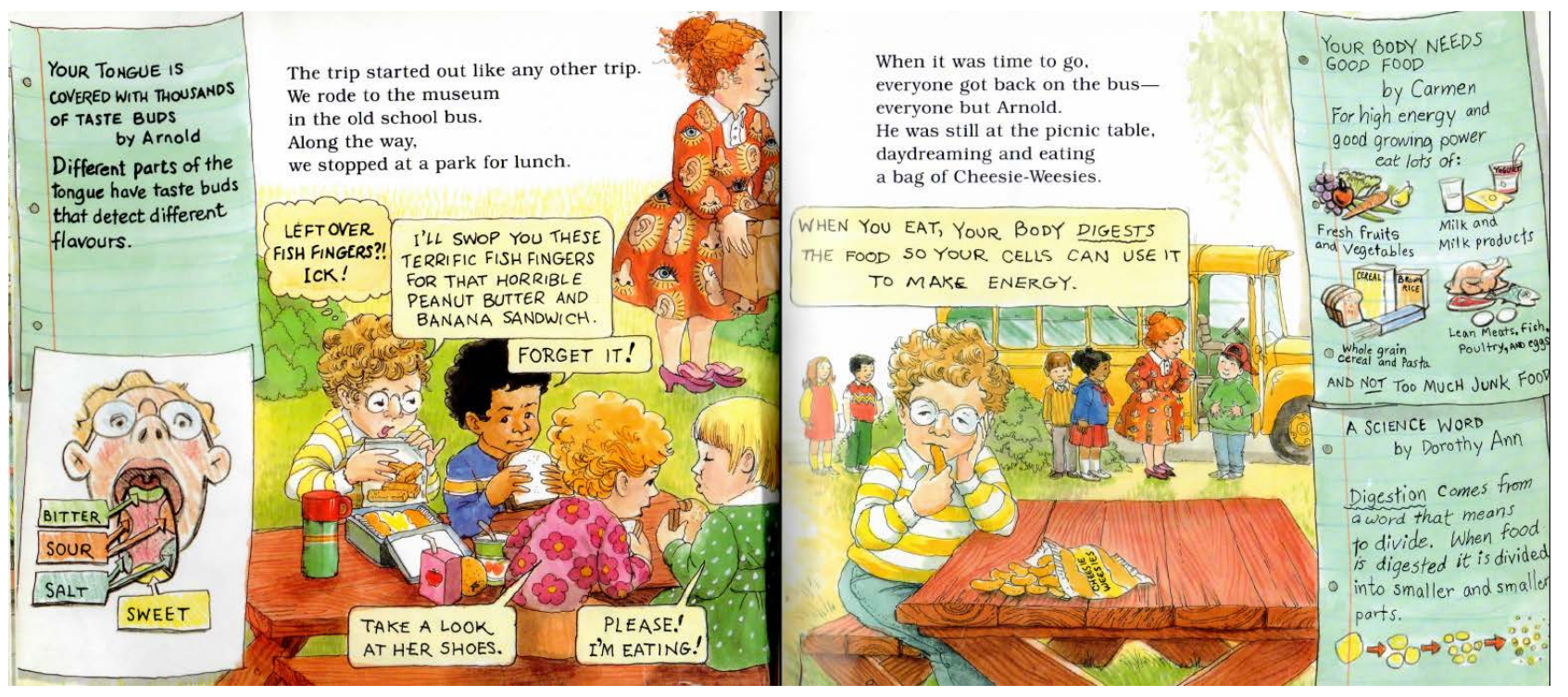

Figure 1. Sample of the double spread of Inside the Human Body. 
human body along with Ms. Frizzle and her class. As an informative picture book requires the learning to be both exciting and informative, Inside the Human Body is formatted in such a way that the readers feel like they're part of the adventure, with information provided in speech bubbles, notebook pages, data files, and ink sketches in almost every page.

The story begins with some activities in Ms. Frizzle's science class illustrated in a double spread: a filmstrip about human body was shown to the class on the screen and six students were sitting there in the picture, however, instead of focusing on the lesson, they were whispering to each other, or otherwise engaged, indicating that the kids are easily distracted in a traditional classroom.

The six students in the picture represent the whole class of more students. The trope of visual metonymy PART FOR WHOLE plays a significant role in the construction of narrative reality transmitted in this picture throughout the book. Their figures, clothes, behaviors, and even their sitting position in the picture all indicate that they are young students, maybe similar to the young viewer in age.

Then Ms. Frizzle announced a fieldtrip to a science museum. On the way to the museum, they stop to have lunch. However, when they get aboard the school bus, they notice that Arnold is still out there eating and daydreaming. Instead of waiting for Arnold or picking him up, Ms. Frizzle manages to drive the magical school bus inside Arnold's body and shepherds the whole class through the body. The students toured around inside the body the whole time.

Two picture metaphors are implied in the narratives of the book once they start their trip. Here are the two metaphors.

1) HUMAN BODY IS MUSEUM. (Hybrid Metaphor)

2) THE SCHOOL BUS IS FOOD. (Contextual Metaphor)

The two picture metaphors link the whole story together. Without them, the plot of the story would be unreasonable.

\subsubsection{Human Body Is Museum}

Museum generally refers to a building in which objects of historical, scientific, artistic, or cultural interest are stored and exhibited. Here in the picture book, human body is similar to a museum in that human body can be regarded as a building in which organs are stored, linked and exhibited. The difference lies in that human body here is alive and moving. Ms. Frizzle plans to drive the class to the museum so that they get to know how human body gets energy from the food eaten. However, instead driving to the museum, they arrive at another "museum" inside a human body, which is illustrated through a series of adventures. In the original plan, the science museum is the destination of the trip, however, instead, they tour around inside a human body, with all the organs being the exhibits, which results in the pictorial metaphor HUMAN BODY IS MUSEUM. Without the illustrations, the viewers may not understand what is going on, or whose body they are visiting.

However, the metaphor is neither narrated nor illustrated directly. Human body and museum are normally distinct entities, but in the narrative, the two 
objects are physically merged into one. When Ms. Frizzle and the class start their tour inside a human body, they begin a tour around a museum. With the help of the dialogue and narrative, the human body and the museum are visually represented as occupying the same space in a manner that is physically impossible. This is a typical example of hybrid metaphor, which is explained as two objects that are normally distinct entities are physically merged into a single gestalt (Forceville, 2008: p. 465).

\subsubsection{School Bus Is Food}

During lunch, Arnold, one of the students in the class, is not satisfied about his lunch. When the lunch break is over, all except Arnold get on the bus. Meanwhile, Arnold still sits at the table, eating and daydreaming. In the picture (see Figure 2), close-ups are given to Arnold and the food on the table in four pictures, with Ms. Frizzle, the rest of the class and the bus on the background. It takes the audience by surprise that the bus starts to shrink and swirl, and finally land on Arnold's palm, mixing with the fish fingers he is eating. In the picture, the shrinking and swirling of the bus is depicted as a cloud, many bigger buses at first, then gradually smaller ones, until it gets lost among the fish fingers on the table. Arnold doesn't notice the changing bus. When he finally looks up while putting a "finger" into his mouse, the bus has gone. The word "Gulp" indicates Arnold has difficulty swallowing the disguised bus at hand. The bus in disguise goes along with food into his body.

When the bus, having been mistakenly swallowed, reappears on the picture again, it is still in the form of a bus but resembles food, with its walls disguised with pictures of bread, watermelons, bananas. The bus goes down the oesophagus along with the food to the stomach, where the food is churned and mashed into a thick liquid. "We are being digested instead." "Now we know what it felt to be a hamburger." Here, the word "digest" can easily be related to food; and the bus is a hamburger. The metaphor is further supported by the dialogue between Ms. Frizzle and her class when they are still in the bus. She tells her class that "the bus is following the path of the food molecules into the blood." One of the students blurts out, "You mean this body thinks we're food?" Hence, the metaphor SCHOOL BUS IS FOOD becomes apparent.

Here the bus is metaphorized as food because of the visual context in which it is placed. First, in the picture it turns smaller and closer towards the foreground, leaving traces of the change illustrated as a cloud of cars, bigger at first, smaller and smaller later. Then the bus lands on Arnold palm in the same size as the fish finger he is eating. In the illustrations, the bus moves along with food, resulting in the pictorial metaphor: SCHOOL BUS IS FOOD. This is an example of context metaphor, which indicates that an object is metaphorized because of the visual context in which it is placed.

The two pictorial metaphors link the whole story together and are so significant for the narrative and plot of the book. Otherwise, the adventure would not sound natural and reasonable. 


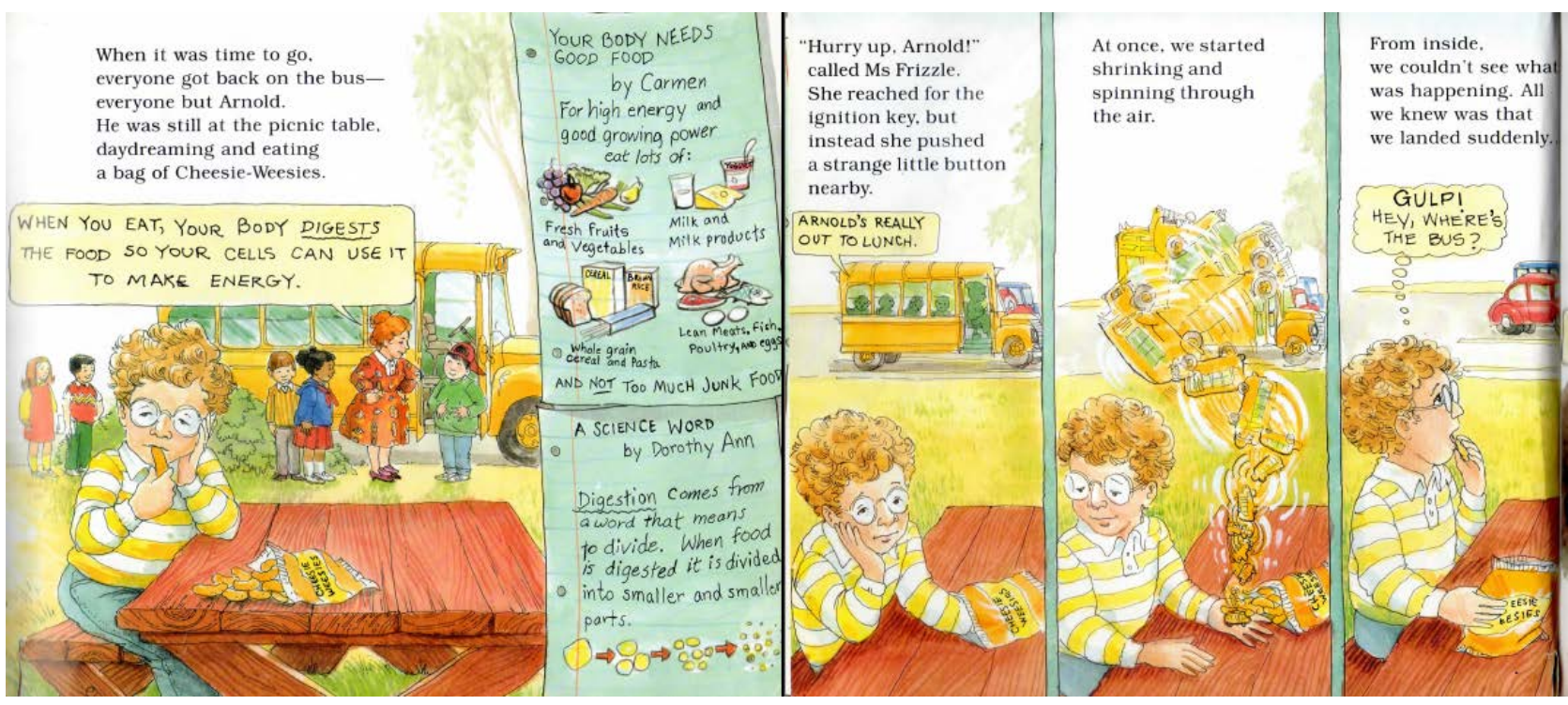

Figure 2. Illustration of the transformation of the school bus.

The trip inside the human body seems as adventurous as any other trip in reality: getting on a bus, getting into the flow, hitchhiking forward, climbing the bones of spine and coming back to school. The trip can be so exciting, stressful and interesting mostly because of two characters, Ms. Frizzle and Arnold. Without them, there would be no trip at all.

\subsection{The Multimodal Design of the Identity Construction of the Main Characters}

This section is going to explore how multimodal designs help the construction of identity of the main characters in the picture book.

As aforementioned, the main characters of each picture book of The Magic School Bus series include the key figure Ms. Frizzle, and the students of her science class. Eight students in the class are identifiable in the illustrations as they rarely change the colors and patterns of their clothes, hair style, or other distinctive features. As each of them is in clothes of different color and pattern, the clothes of a certain color and pattern may be used metonymically to refer to a certain person. These visual metonymies are used frequently in the picture books. Previous studies have explored the functions of visual metonymies in picture books: to enhance children's understanding of stories, to transmit related messages of the narrative content of the stories to the young readers, to create narrative tension in the plot, and form a bond between the characters in the story and the young viewer (Forceville, 2009a: pp. 56-74; Jesús Moya Guijarro, 2013: pp. 336-352).

However, two characters are depicted in great detail so that they build their particularly distinctive characteristics, Ms. Frizzle and Arnold. Thus, the study is going to focus on the two figures meticulously depicted: Ms. Frizzle, the teacher and Arnold, a reluctant student. 


\subsubsection{Ms. Frizzle: An Eccentric and Adventurous Teacher}

Similar to online live videos, the identity of the character in children's picture books is jointly constructed by multimodal resources such as discourse, gesture, action, costume, and physical context (Chen, 2014; Wang \& Feng, 2020: pp. 66-76).

As described at the very beginning of the picture book, Ms. Frizzle is the "strangest" teacher in the school. As a teacher like no other, she's bold and offbeat. But she loves science so much that she would brave difficulties to drive or fly the magic school bus and push the class through various adventures. However, her weirdness is much easier said than illustrated.

In the picture book, Ms. Frizzle is illustrated as a middle-aged woman in curly entangled red hair. She usually behaves in a calm and confident manner no matter what adventures or dangers they are in. Her science class is very well organized. She seldom loses control and is always ready to deal with any difficulty that comes her way.

The characters are usually depicted with certain evaluative attributes. In Inside the Human Body, Ms. Frizzle is a teacher, to be specific, a science teacher. However, she is the "strangest" science teacher. So "strangeness" is one of her evaluative attributes. Book reviews usually depicts her as bold, offbeat, and kind of wacky. But in what way can strangeness be illustrated.

Bruce Degen, the illustrator of Inside the Human Body depicts Ms. Frizzle's strangeness through her outfits and actions. In the picture book, the patterns of her clothes are generally symbolic. Usually, the patterns of her first outfit are related to the theme of their previous science project, while the last previews the theme of their next project. The patterns of the rest outfits in the illustrations are mostly in tune with the theme of the present project.

In Inside the Human Body, Ms. Frizzle is seen in five outfits of different patterns.

Her first outfit is a traditional long-sleeve skirt in light blue, with the pattern of many frogs squatting at the bottom with their red long tongues sticking out to catch the flies over the top of their head. The accessories are breathtaking: the earrings of green dragonflies and shoes decorated with pitcher plant, the carnivorous plant. And the patterns of her second outfit are a yellow skirt with many tadpoles swimming and growing bigger and darker, and frogs, small and large. And there are paintings of cow and cat on the wall. The two outfits indicate that their previous project is related to the animals and insects.

The third outfit is a red dress in the pattern of eyes, noses, ears and fingers, and a pair of shoes with the decoration of tongues. Another outfit is a yellowing green dress with the pattern of lung cells, muscle cells and brain cells. These two outfits show that the theme of this lesson is human body. The last outfit is a blue dress with the pattern of launching rockets, bigger at the bottom, getting smaller up in the air, with stars as her earrings and the model of Saturn as the decoration of her shoes, which predicts that their next trip might be the outer space.

In the picture book, the patterns and accessories of Ms. Frizzle's clothes are examples of visual metonymy, PART FOR WHOLE. All the illustrations of Ms. 
Frizzle's outfits lead to the conclusion that Ms. Frizzle is truly a science teacher of eccentric personality. That's her major identity.

Besides, her science class is different from ordinary classroom learning in that her students learn mostly through hands-on adventures outside the classroom or even the school. As long as she is behind the wheel of the magic school bus, anything can happen. And there will always be "a change of plan". The destination of the hands-on adventures can be the bottom of deep ocean, the center of the earth, outer space, water pipeline in the city or go back to the past, nothing is impossible. That makes her adventurous and her class exciting and interesting.

Four reporting verbs have been used in the direct and indirect quotations of Ms. Frizzle for 14 times in total, namely say (10 times), announce (1), explain (2) and call (1). According to the evaluation of reporting verbs put forward in Thompson \& Ye (1991), these verbs are all neutral in stance, but the word "announce" indicates Ms. Frizzle's authority, and "call" shows that she can be emotional occasionally when she senses danger.

Ms. Frizzle is certainly not only an eccentric science teacher. She is adventurous, well-organized, and capable of inspiring her students' interest in whatever they are learning. These identities are all projected directly or indirectly in the narrative and visual metonymies in the picture book.

\subsubsection{Arnold: A Reluctant but Popular Student}

Arnold is the only students in Ms. Frizzle with his name mentioned over and over again in each book of The Magic School Bus series. And he is the only bespectacled kid in the class with curly blond hair, always wearing a T-shirt of yellow and white stripes and blue jeans.

At the very beginning, the speech burbles show that when Ms. Frizzle specifically addresses him smilingly by saying that the theme of human body should interest him, while Arnold, sitting at the back of the class, with his arms heavily laying on the back of his chair, does not focus on the ongoing filmstrip, looking elsewhere, thinking, "I can't take the stress." "Just being in Ms. Frizzle's class takes all my energy." He is not an active student so that he often intends to back off at Ms. Frizzle's suggestion of trips, but at the same time he cannot restrain his curiosity. He tags along, and learns as well. He is reluctant, or not as active as his classmates.

At the lunch table, he complains about his lunch with words like "left over", "ick". He tries unsuccessfully to swop his lunch with his classmate. After lunch, when all the class is ready to get on the bus to continue their trip, Arnold still sits on the table, daydreaming while eating. In the picture, Arnold is illustrated sitting at the table in the foreground, staring at his right, with one hand holding his right chin, while the other hand extending inside a bag of cheesie-weesies. In the background, Ms. Frizzle is explaining to the rest of the class how body digests. His absentmindedness explains why he fails to notice what is happening to the bus behind him, and why he would swallow the shrunken bus without noticing much of a difference (see Figure 2). 
However, it is not different to notice that Arnold is quite popular among his classmates. When he fails to get on the bus, his classmates are very upset by leaving him behind. During the tour, they think it is a pity that Arnold is not travelling and touring along with them, and they wonder where Arnold is the whole time. When they finally meet Arnold at the school park lot, they all seem surprised and excited. In the illustration, his classmates are running towards Arnold, with their arms extending to give him a hug. And Arnold, arms open, is ready to hug them too. Only four or five students are illustrated in the picture, representing the whole class.

Visual metonymies and dialogues in the speech burbles make the identity of Arnold's personality quite clear: reluctant while popular.

On the website of the bookshop link, many messages left by young and adult viewers say that Arnold is their favorite character in the book (the comments link of the book series in the online bookstore:

http://product.dangdang.com/25252408.html?point=comment point). His reluctance and popularity make him stand out of the rest of the class.

The other four or five students in the class are an example of metonymy, referring to the whole class, and they are typical of primary school pupils: whispering or chitchating in class, complaining about and commenting on Ms. Frizzle's outfits or arrangement, and encouraging or supporting each other when in difficulty. The verbal and visual depicts of the other students might remind the young viewers of their own classmates.

\subsection{The Pictorial and Multimodal Metaphors in Inside the Human Body}

To help children of 4 to 8 understand how the body works correctly, the informational picture book needs to impart the information accurately and understandably. Given children's limited experience in life and science, accurate information of human body needs to be explained in a simple and clear language. To serve the purpose, metaphors are employed to satisfy all requirements as metaphor unites reason and imagination. As categorization, entailment and inference are part of reasoning important to understand scientific information, and imagination can help explain one thing in terms of another kind of thing, metaphor is imaginative rationality (Lakoff \& Johnson, 1980: pp. 193-194).

Besides the two pictorial metaphors cued, namely HUMAN BODY IS MESUEM and SCHOOL BUS IS FOOD, many verbal metaphors, metonymies and similes are employed in the picture book, combined with visual tropes, to make the facts and ideas understandable to the young readers.

In this part, all the messages in Inside the Human Body will be analyzed to find out verbal and pictorial metaphors in the speech bubbles, notebook pages, data files and ink sketches on the wall of the classroom. Besides, tropes that will be under discussion include those that reflect human thought and action, indicate similarities, and provide an understanding of one kind of experience in 
terms of another, e.g., metonymy, simile and personification (Lakoff \& Johnson, 1980: p. 153).

\subsubsection{Multimodal Metaphors: Interaction between Verbal and Pictorial Metaphors}

Our knowledge of the world can be acquired through experiencing the objects in it, and getting to know the properties of the objects and the interrelations of these objects (ibid: 187).

Inside the Human Body contains many verbal and pictorial metaphors. In most cases, the paradigmatic NOUN A IS NOUN B formula is employed. Table 1 indicates that the targets and sources in these multimodal metaphors are concrete entities, with the target being an organ inside the human body, and the source an entity familiar to young viewers, with certain mapped features.

A thorough analysis of Inside the Human Body leads us to a summary of verbal and pictorial metaphors as listed in Table 1, where the pictorial metaphors are verbally described.

Table 1 shows that the paradigmatic NOUN A IS NOUN B formula is the typical and conventional verbal metaphors. Similarly, in the illustrations, almost all pictorial metaphors are illustrated with two pictorially present terms (MP2), i.e., both the target and source subjects of the metaphor are presented in the pictures. Both verbal and pictorial metaphors interact with each other and make the information easily understood by the target young viewers.

As is known, pictures are more international than words, the pictorial metaphors in the picture book can almost stand on its own. Take Figure 3 for example, NOUN A IS NOUN B formula is applied here: INTESTINE IS COILED-UP TUBE. In the illustration, a boy in blue pullover is standing there, with the sketch of his belly showing the position and structure of his oesophagus and stomach in green and the coiled-up intestine in brown. Next to the boy is still the same boy, but he is three times taller than the first boy, with his intestine stretching out straight, an imaginative and hypothetical condition. The sketch not only shows the appearance and location of the intestine inside the body, but also shows the children the real length of the intestine in an interesting way.

Table 1. Primary subjects, secondary subjects and projected features in verbal and pictorial metaphors.

\begin{tabular}{|c|c|c|c|}
\hline Primary subjects & Secondary subjects & Projected features in verbal metaphors & Projected features in pictorial metaphors \\
\hline Oesophagus & Tunnel & Tube that connects, a passageway through & The bus drives out of a dark tunnel \\
\hline $\begin{array}{l}\text { Food through } \\
\text { oesophagus to stomach }\end{array}$ & Toothpaste in a tube & Squeeze, push & $\begin{array}{l}\text { The section of a tube with a black spot at the } \\
\text { lower end moving upward. }\end{array}$ \\
\hline Intestine & Tube & Coiled up, hollow, long & Coiled-up, long \\
\hline Villi & Fingers & Physical similarity; Tiny Finger-like structures & Layers of finger-like structures laying together \\
\hline Heart & House & Multiple chambers inside & 4 chambers \\
\hline Chambers & Pump & $\begin{array}{l}\text { Hollow; to move fluid or gas by pressure or } \\
\text { suction }\end{array}$ & $\begin{array}{l}\text { Chambers with arrows indicating the moving } \\
\text { direction }\end{array}$ \\
\hline Body & Cycle & Blood circulates inside the body & Blood vessels moving all through the body \\
\hline
\end{tabular}




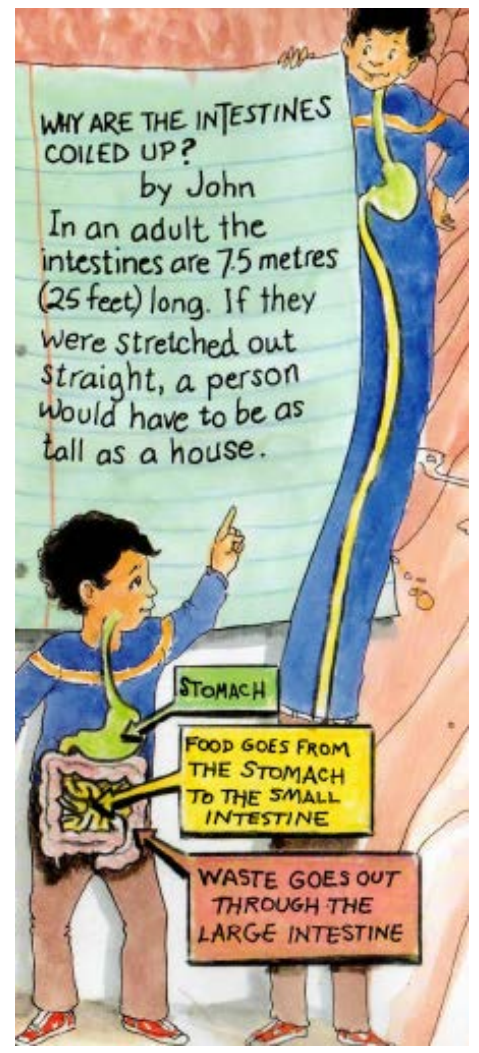

Figure 3. Sketch of the intestines.

Besides the metaphors listed in Table 1, some facts and ideas are represented through the combined efforts of verbal and pictorial metaphors. Here are a few cued metaphors:

1) THE BONE OF SPINE IS THE TRUNK OF A TREE.

2) NERVE CELLS ARE THE BRANCHES OF A TREE.

3) DISEASE GERMS ARE ENEMIES.

Figure 4 demonstrates two metaphors. In the illustration, Metaphors (1) and (2) are interrelated with each other. The illustration of the bone of spine is similar to the trunk of a tree, and the nerve cells look like the branches of the tree. The verbal metaphors are cued through the descriptions, such as "climbing down the bone of the spine", "Smaller bundles of nerve cells branched out from each side of the spinal cord". The pictorial representations are much easier to understand. All these lead to the metaphors: THE BONE OF SPINE IS THE TRUNK OF A TREE; NERVE CELLS ARE THE BRANCHES OF A TREE.

Figure 5 represents Metaphor (3), where white blood cells are compared to soldiers protecting one from enemies. In the illustration, the idea is demonstrated as a computer game like Feeding Frenzy, with the white blood cells spotting, chasing, swallowing the disease germs and breaking them into pieces. Even if the children are not familiar with the game, they can still understand what is going on. The verbal and pictorial metaphors interact to represent the metaphor: DISEASE GERMS ARE ENEMIES. 


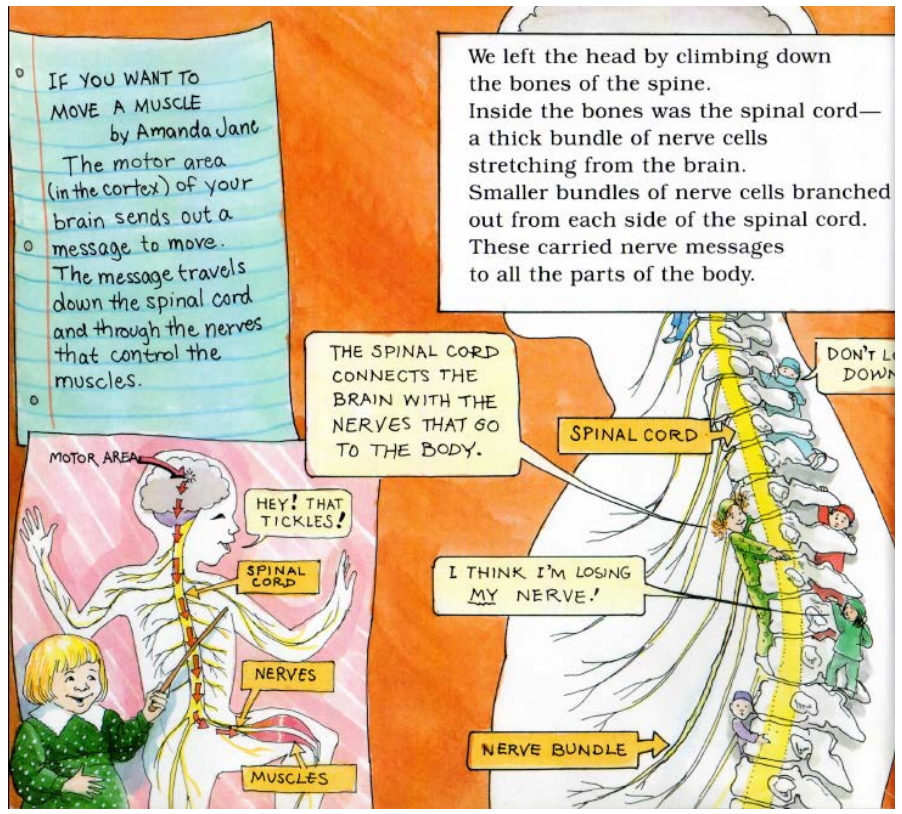

Figure 4. Illustration of the bone of spine.

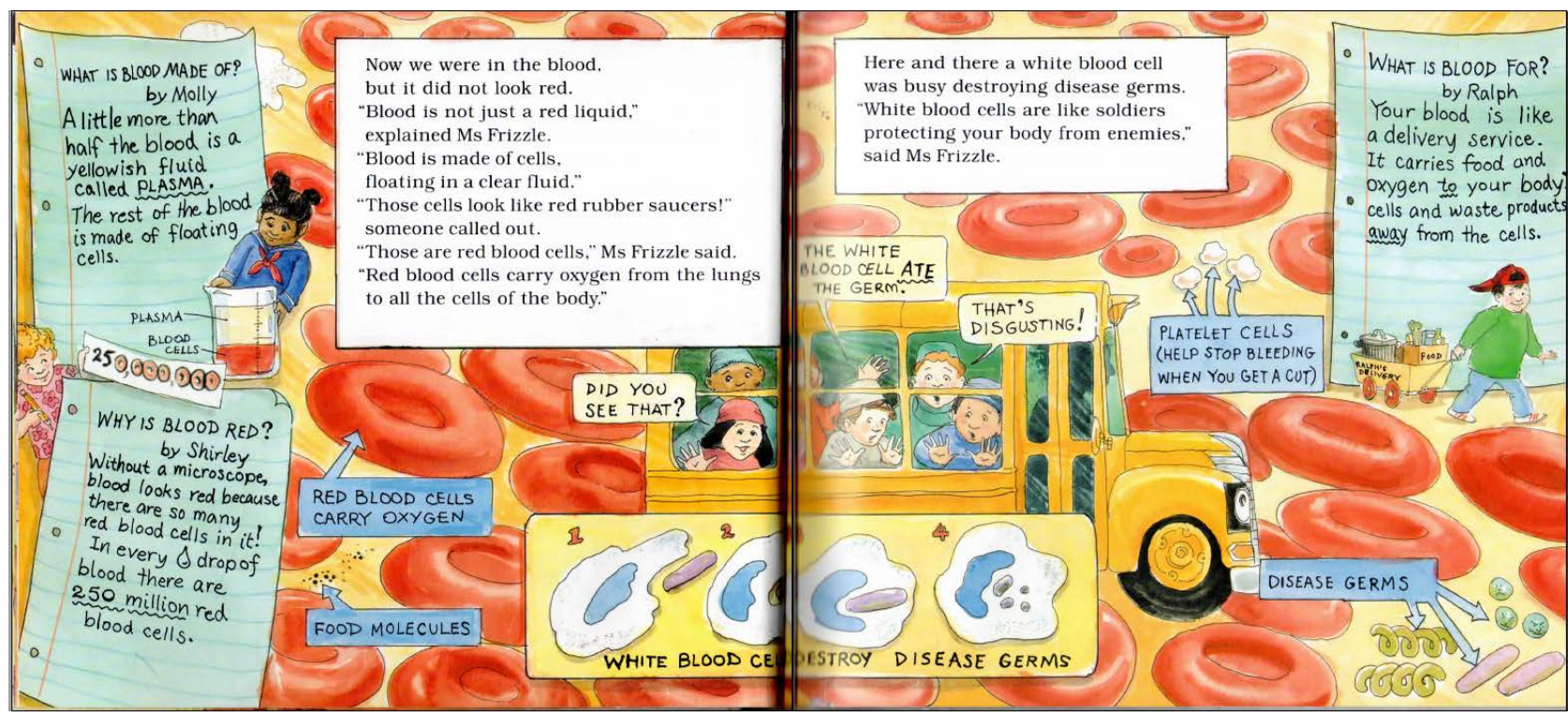

Figure 5. Illustration of the white and red blood cells.

\subsubsection{Similes and Pictorial Metaphor}

Simile indicates a resemblance between things of different kinds. It is usually employed to show the similarities between different things. Similes are considered as weaker and more explicit, as well as to invite fusion between primary subject and secondary subject to a lesser extent, than their corresponding metaphors (Lakoff \& Johnson, 1980). The formula NOUN A IS LIKE (AS) NOUN B presents both the primary and secondary subjects, and their similarities are clearly stated.

Many similes are used to compare organs inside human body with things of everyday life, with which the children are more familiar. 
For example, on the top right conner of Figure 5 is a sketch of a simile, which reads "your blood is like a delivery service. It carries food and oxygen to your body cells and waste product away from the cells."

Apparently, the explanation tells the young viewer the similarity between blood and delivery service: to deliver goods. The major difference lies in the fact that blood delivers food and oxygen to body cells, and it carries waste away. And the simile is illustrated in a sketch: a boy in green pullover and a red cap dragging a cart filled with food box and dustbin. The verbal simile and pictorial metaphor combine to state the metaphorical fact: blood serves as a delivery man. Here, only the source entity is represented in the picture, an example of MP1s, the metaphor with one pictorially present term.

Here are a few similes employed in the picture book.

1) Your stomach is like a built-in food processor.

2) Your blood is like a delivery service.

3) Red blood cells look like rubber saucers.

4) White blood cells are like soldiers protecting our body from enemies.

5) Blood vessels are like pipelines running through your body.

It is not difficult to notice that the similes employed here are not only a part of speech, but a mode of thoughts or actions.

Simile (1) compares stomach to an inbuild food processor. The primary subject is an organ, while the secondary subject is a kitchen utensil. The two are in different categories, but both serve the same purpose: to deal with food inside by churning and mashing food. Sometimes both may even make the same noise: gurgle. In the illustration, on one side, the school bus is being churned and mashed inside the stomach, on the other side, a boy is operating a food processor, and on his green sweater is a picture of a hamburger where his stomach is. Here hamburger is a metonymy for all food. The simile and the pictorial metaphor result in the fact that stomach is an inbuild food processor. Here, all the subjects are pictorially presented, a typical example of MP2. So is Simile (2).

However, Simile (3) and Simile (4) are different in that the comparisons in the similes are not represented with the same secondary subjects in pictorial metaphors. In (3), red blood cells are compared to rubber sauce which is familiar to kids, because they share the same color and same round shape. The illustration, however, paints red blood cells more like red life buoys. Life buoys are round and life-saving, and they are designed to provide buoyancy to prevent drowning, similar to the function of red blood cells. And their function as a safe transportation for the class makes it even more reasonable.

Simile (4) makes a comparison between white blood cells and soldiers as they serve the same purposing of fighting and protecting people from enemies, here the disease germs. A sketch on the low left corner of the page (see Figure 5) depicts the disease germs as worms, evil and disgusting, not the kind of enemies we are in mind. The pictorial metaphor is represented as a computer game of chasing and swallowing, meaning the white blood cells protect human body by chas- 
ing after the harmful germs and destroying them. All these ideas are correctly and accurately presented verbally and pictorially.

\subsubsection{Personification and Metaphors}

Personification, a general category covering a wide range of metaphors, is "the most obvious ontological metaphor", where we make sense of the physical object in human terms, which are easily understood on the basis of our own thoughts, goals, actions, and characteristics (Lakoff \& Johnson, 1980: pp. 33-34).

In Inside the Human Body, the use of personifications makes the explanation and description vivid and easier to understand. The capitalized words in the following sentences are personifications. Some are represented in pictorial metaphors, and some are only depicted verbally.

a) Why does stomach GROWL?

b) That white blood cell must THINK the school bus is a germ.

c) The white blood cell ATE the germ.

d) Red blood cells CARRY oxygen from the lungs to all the cells of the body.

e) Looking back, we saw a white blood cell CHASING the bus.

f) In the lungs, the red cells PICKED UP fresh oxygen.

g) ... these red blood cells are ON THEIR WAY to the brain.

h) Your brain never LIES DOWN on the job.

As described in a), stomach does make sounds, but as picture books cannot manifest vocal sound, onomatopoeic terms are used. "Growl" and "gurgle" vividly mimic the sound.

In Figure 6, the white blood cell, "thinking" the school bus as a germ, is chasing after the bus. Personifications b), c) and e) are all based on the personification of white blood cells as humans. The chasing is illustrated as the white blood cell flows behind the bus, trying to swallow it. As children are familiar with chasing and eating, the personification and illustration make it interesting and easy to understand the function of white blood cells.

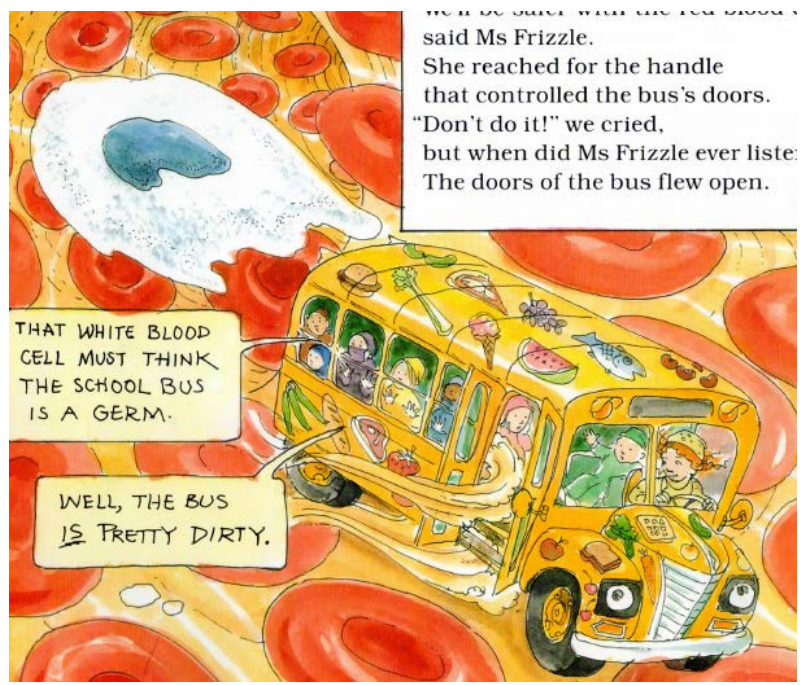

Figure 6. Illustration of a white blood cells chasing the bus. 
In Figure 7, the sketch shows that it is 3 o'clock, a kid is lying in bed, sound sleeping while his brain is still working. It indicates that the brain never lies down, meaning: it never takes a break.

To sum up, personality makes the information and the narration vivid and clear, and the illustration enhances the effect.

\subsubsection{Pictorial Metonymy and Metaphors}

Cognitive linguists consider metonymy to be the younger sister of metaphor, to convey meaning and represent reality (Forceville, 2009a). Different from the fact that in metaphor, source and target are from two different domains, in the case of metonymy, the target and source are part of the same conceptual domain.

In Figure 8, the school bus is coming out of a dark tunnel. Only part of the tunnel is visible, referring to the whole oesophagus. And the students inside the school bus are sketched as round faces with 4 black spots on it, indicating their eyes, the nose and the mouth. This is a case of the metonymy PART FOR WHOLE. Similarly, Figure 9 shows us the section of the nose and mouth, common sense tells us they represent the inner section of nose, teeth and tongue, although without the context created by verbal description, it is really hard to understand the illustration.

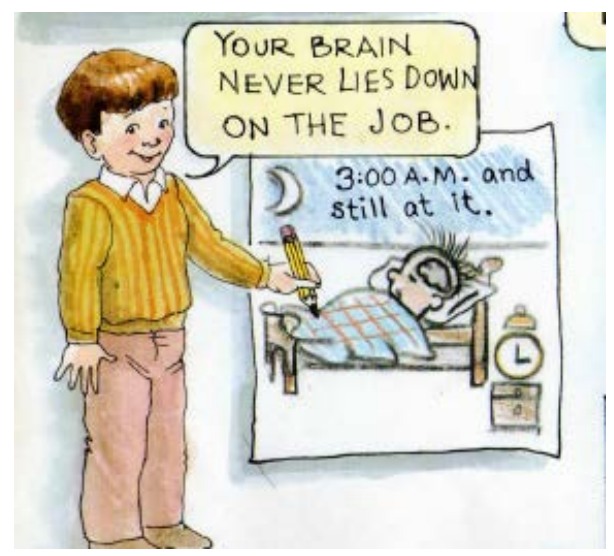

Figure 7. Sketch of your brain never lies down.

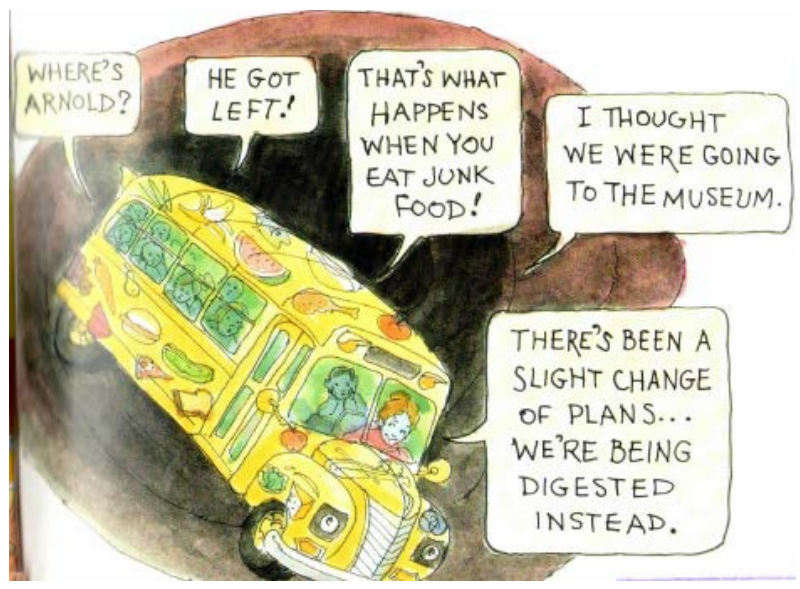

Figure 8. Illustration of OESOPHAGUS IS TUNNEL. 


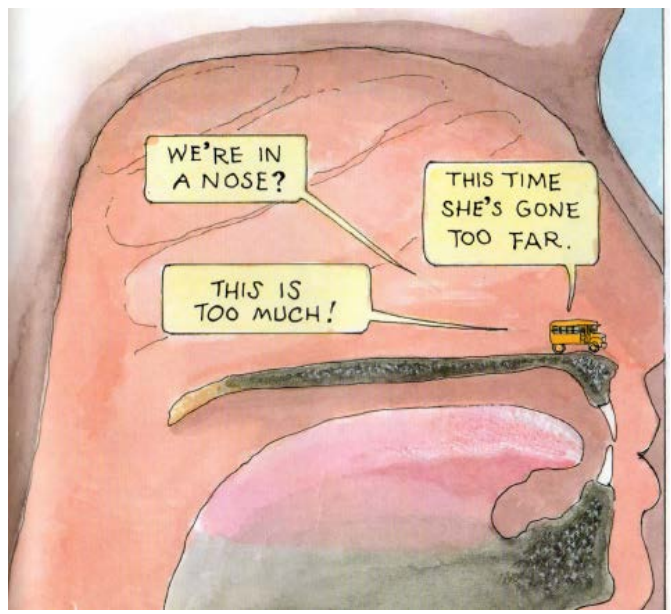

Figure 9. Illustration of the inner section of the nose and mouth.

There are examples of metonymy in the verbal manifestation of language as well.

Scene 1: When the class tour around the heart (1), a student in green says, "Have a heart (2), Ms. Frizzle, get us out here!"

Scene 2: Ms. Frizzle notices that the red blood cells are on their way to the brain (1), meanwhile Arnold gets lost, looking puzzled, saying "Which way back to school?" A red bird replies, "Use your brain (2)."

Scene 3: When the class is climbing down the bone of spine full of a thick bundle of nerve (1) cells, the student in green says, "I am losing my nerve (2)."

Here, heart (1), brain (1) and nerve (1) refer to the organ inside human body, while heart (2), brain (2), and nerve (2) are used metaphorically. Heart (2) is used metaphorically as the locus of feeling and intuitions. "To have a heart" means to be merciful. Brain (2) refers to mental capacity or wit. Nerve (2) refers to strength or courage.

These are cases of the metonymy THE CONCRETE FOR ABSTACT, specifically, THE ORGAN FOR THE FUNCTION here.

To sum up, in this section, a disintegration analysis has been carried out to uncover the pictorial and multimodal metaphors employed in Inside the Human Body from three dimensions, which indicates that metaphors are an indispensable feature of the informational picture book.

\section{Discussion}

Besides the observations in the analysis of Inside the Human Body, there is more to it than has been explored. Based on the results of the analysis, a few aspects are to be discussed further in this section to answer the questions raised in the introduction.

First, the analysis shows that two pictorial metaphors, namely, context metaphor THE SCHOOL BUS IS FOOD and hybrid metaphor HUMAN BODY IS MUSEUM, are employed in the construction of the narrative reality transmitted 
in this picture book, which not only make the plot of the story reasonable and interesting, but also helps the young viewers to have a thorough understanding of the whole story.

The identities of the two main characters in Inside the Human Body have been constructed through multimodal design. Ms. Frizzle is identified as the strangest, most adventurous and inspiring science teacher. Her identity is constructed with the illustrations of the weird patterns on her dress, her bold behaviors and her exquisite plans for her science projects, both verbally and pictorially. Arnold, a student in the class, is identifiable as a reluctant while popular boy in the class. He is absentminded, and always reluctant to participate in the adventure, but he is popular among his classmates. His personality is also constructed verbally and pictorially.

As an informational picture book, knowledge of human body should be an important part of the picture book. A chunk of information about inside the human body is presented pictorially and verbally in the book. Besides the narration on almost every page, verbal expressions also include the written information with the speech bubbles, notebook pages, data files and ink sketches on the wall. Speech bubbles represent the interesting dialogues between a few students or students and Ms. Frizzle. Some dialogues are the complaints made by the students of the trip or Ms. Frizzle; some are closely related to the theme of the illustration. Data files and ink sketches are mostly in the form of reports hanging on the wall with information collected by the students and presented in verbally and pictorially. Most of the information presented is in the language of the students, which makes it closer and even more attractive to the young viewers.

Multimodal metaphors are employed to make the complex and abstract concept easier to understand. Verbal metaphors (including similes, metonymies, personifications) are frequently used for the purpose. And most of the verbal metaphors are represented pictorially. Among the four types of pictorial metaphor proposed by Forceville (1996), metaphors with two pictorially present terms (MP2) and verbo-pictorial metaphors (VPMs) are more frequently employed. It is quite reasonable, as conveying information is very important function of the informational picture book for children of 4 to 8 . However, as some of the viewers may not be able to read and understand the information by themselves, with the help of illustrations and the comparison of strange concepts with the ones they are familiar, even the youngest viewers can have a general idea of the story and the message. Multimodal metaphors facilitate the information picture book to convey information accurately and narrate the story interestingly.

There is another prominent feature that cannot be ignored in the picture book. Although it is impossible to add voice to the paperback picture book, to make up for the deficiency, the author makes use of many interjections and onomatopoeic words to vividly capture the emotions of the students and mimic the sound in the tour such as aaah, oooh, ick, choooo, gurgle, yuck, thud, pant, and etc. which may give some clue to the composing of future picture books. 


\section{Conclusion}

In this article, the author aimed to demonstrate how pictorial and multimodal metaphors contribute to the representation of information in a picture book for children: Inside the Human Body. The results of the analysis show that pictorial and multimodal metaphors are an indispensable part of the book.

Firstly, two pictorial metaphors, namely a context and a hybrid metaphor, are employed in the construction of the narrative reality transmitted in this picture book, which makes the whole adventure reasonable and interesting.

Secondly, the picture book resorts to multimodal designs to construct the unique identities of its main characters, namely, Ms. Frizzle, the science teacher, and Arnold, a student in Ms. Frizzle's class. Their identities are all represented verbally and pictorially, with Ms. Frizzle, an eccentric and adventurous teacher, and Arnold, the reluctant but popular student in the class. Ms. Frizzle's weirdness is demonstrated mostly through the patterns on her outfits and her behaviors all through the adventure. Arnold reluctance in taking part in the class activities is shown through his facial expression and body language in the illustrations.

Thirdly, to convey the complicated and abstract concepts to children, the text writer and the illustrator of the information picture book collaborate to present the concepts and information through the interaction of various types of pictorial and multimodal metaphors. Metaphors here are used in a broad sense, including metaphors, similes, metonymies and personifications as proposed by Lakoff \& Johnson (1980).

The analysis carried out also reveals that most of the pictorial metaphors are represented with two pictorially present terms (MP2) and verbo-pictorial metaphors (VPMs). As the two types of pictorial metaphors can be easily understood by the target young viewers from cognitive perspective.

Writers and illustrators need to know how pictorial and multimodal metaphors may be exploited to convey complicated and abstract information to the young viewers within their cognitive capacities. Pictorial and multimodal metaphors are essential in informational picture books for children.

However, as the study is only based on one informational picture book, and the analysis of metaphors is inevitably subjective, further study shall be carried out to address the two flaws by analyzing more picture books from Magic School Bus series; and surveys of the opinions of the target readers or viewers shall be conducted, taking their cultural background into account.

\section{Conflicts of Interest}

The author declares no conflicts of interest regarding the publication of this paper.

\section{References}

Bounegru, L., \& Forceville, C. (2011). Metaphors in Editorial Cartoons Representing the 
Global Financial Crisis. Visual Communication, 10, 209-229. https://doi.org/10.1177\%2F1470357211398446

Chen X. (2014). Current Research on Identity from the Pragmatic Perspective: Key Issues and Main Approaches. Ph.D. Thesis, Nanjing University.

Cole, J. (1990). The Magic School Bus-Inside the Human Body. New York: Scholastic Press.

Dong, W. M. (2014). Metaphor Cognition and its Educational Application in Children Aged from 3 to 6. Ph.D. Thesis, Zhejiang University.

El Refaie, E. (2003). Understanding Visual Metaphors: The Example of Newspaper Cartoons. Visual Communication, 2, 75-95.

https://doi.org/10.1177\%2F1470357203002001755

Forceville, C. (1996). Pictorial Metaphor in Advertising. Routledge.

Forceville, C. (1999). The Metaphor “COLIN IS A CHILD” in Ian McEwan's, Harold Pinter's, and Paul Schrader's. The Comfort of Strangers. Metaphor and Symbol, 14, 179-198. https://doi.org/10.1207/S15327868MS140302

Forceville, C. (2002). The Identification of Target and Source in Pictorial Metaphors. Journal of Pragmatics, 34, 1-4. https://doi.org/10.1016/S0378-2166(01)00007-8

Forceville, C. (2006). Non-Verbal and Multimodal Metaphor in a Cognitive Framework. Agendas for Research. In G. Kristiansen, M. Achard, R. Dirven, \& F. Ruiz de Mendoza (Eds.), Cognitive Linguistics: Current Applications and Future Perspectives (pp. 379-402). Mouton de Gruyter.

Forceville, C. (2007). Multimodal Metaphor in Ten Dutch TV Commercials. The Public Journal of Semiotics, 1, 15-34. https://doi.org/10.37693/pjos.2007.1.8812

Forceville, C. (2008). Metaphors in Pictures and Multimodal Representations. In W. R. Gibbs (Ed.), The Cambridge Handbook of Metaphor and Thought (pp. 462-482). Cambridge University Press. https://doi.org/10.1017/CBO9780511816802.028

Forceville, C. (2009a). Metonymy in Visual and Audiovisual Discourse. In E. Ventola, \& A. J. Moya, (Eds.), The World Told and the World Shown: Multisemiotic Issues (pp. 57-74). Basingstoke.

Forceville, C. (2009b). Non-Verbal and Multimodal Metaphor in a Cognitive Framework: Agendas for Research. In C. Forceville, \& E. Urios-Aparisi (Eds.), Multimodal Metaphor (pp. 19-44). Mouton de Gruyter.

Forceville, C. (2016). Visual and Multimodal Metaphor in Film: Charting the Field. In K. Fahlenbrach (Ed), Embodied Metaphors in Film, Television and Video Games: Cognitive Approaches (pp. 17-32). Routledge. https://doi.org/10.4324/9781315724522-2

Forceville, C., \& Urios-Aparisi, E. (Eds.) (2009). Multimodal Metaphor. Mouton de Gruyter.

Gibbs, W. R. (Eds.) (2008). The Cambridge Handbook of Metaphor and Thought. Cambridge University Press. https://doi.org/10.1017/CBO9780511816802

Johnson, M. (1987). The Body in the Mind: The Bodily Basis of Meaning, Imagination and Reason. University of Chicago Press. https://doi.org/10.7208/chicago/9780226177847.001.0001

Johnson, M. (1993). Moral Imagination: Implications of Cognitive Science for Ethics. University of Chicago Press. https://doi.org/10.7208/chicago/9780226223230.001.0001

Johnson, M. (2007). The Meaning of the Body: Aesthetics of Human Understanding. University of Chicago Press.

Kress, G. (2010). Multimodality: A Social Semiotic Approach to Contemporary Communication. Routledge. 
Lakoff, G. (1987). Women, Fire and Dangerous Things: What Categories Reveal about the Mind. University of Chicago Press. https://doi.org/10.7208/chicago/9780226471013.001.0001

Lakoff, G. (1993). The Contemporary Theory of Metaphor. In A. Ortony (Ed.), Metaphor and Thought (2nd ed., pp. 202-251). Cambridge University Press. https://doi.org/10.1017/CBO9781139173865.013

Lakoff, G., \& Johnson, M. (1980). Metaphors We Live By. University of Chicago Press.

Ma, T. H., \& Gao, Y. (2020). Multimodal Metaphor Construction and Critical Analysis of American Political Cartoons: The Case of the U.S.-China Trade Conflict. Foreign Language Research, 1, 25-32. https://doi.org/10.13978/j.cnki.wyyj.2020.01.005

McQuarrie, E. F., \& Phillips, B. J. (Eds.) (2008). Go Figure! New Directions in Advertising Rhetoric. ME Sharpe.

Meng, L. (2019). Multimodal Construction of the Meaning of Death in the Narrative of English Children's Picture Book: Multimodal Narrative Analysis of Is Daddy Coming Back in a Minute? Journal of PLA University of Foreign Languages, 1, 12-19.

Jesús Moya Guijarro, A. (2013). Visual Metonymy in Children's Picture Books. Review of Cognitive Linguistics, 11, 336-352. https://doi.org/10.1075/rcl.11.2.08moy

Ortony, A. (Ed.) (1979). Metaphor and Thought. Cambridge University Press.

Rohdin, M. (2009). Multimodal Metaphor in Classical Film Theory from the 1920s to the 1950s. In C. Forceville, \& E. Urios-Aparisi (Eds.), Multimodal Metaphor (pp. 403-428). Mouton de Gruyter.

Schilperoord, J., \& Maes, A. (2009). Visual Metaphoric Conceptualization in Editorial Cartoons. In C. Forceville, \& E. Urios-Aparisi (Eds.), Multimodal Metaphor (pp. 213-240). Mouton de Gruyter.

Seitz, J. A. (1997). The Development of Metaphoric Understanding: Implications for a Theory of Creativity. Creativity Research Journal, 10, 347-353. https://doi.org/10.1207/s15326934crj1004 6

Siltane, S. A. (1986). "Butterflies Are Rainbows": A Developmental Investigation of Metaphor Comprehension. Communication Education, 35, 1-12. https://doi.org/10.1080/03634528609388314

Thompson, G., \& Ye, Y. Y. (1991). Evaluation in the Reporting Verbs Used in Academic Papers. Applied Linguistics, 12, 365-382. https://doi.org/10.1093/applin/12.4.365

Turner, M. (1996). The Literary Mind. Oxford University Press.

Wang, H., \& Xin, B. (2019). On the Construction of China's Image by US Media Based on a Critical Metaphor Analysis of News Coverage on "US Withdrawal from TPP". Foreign Language Education, 3, 32-38.

Wang, J. (2013). Preschool Children's Reading Comprehension of Informational Picture Books. Ph.D. Thesis, East China Normal University.

Wang, X. P., \& Wang, J. (2018). On the Representation Forms of Dynamic Multimodal Metaphors in Advertising: Properties of Modal Usage and Motivations. Foreign Language Research, 5, 47-52.

Wang, Y. L., \& Feng, D. Z. (2020). Multimodal Construction of Online Media and Female Identity-Taking Douyu Live Video as an Example. Foreign Language Studies, 00, 66-76.

Whittock, T. (1990). Metaphor and Film. Cambridge University Press.

Wiggin, A. A., \& Miller, C. M. (2003). “Uncle Sam Wants You!” Exploring Verbal-Visual Juxtapositions in Elevision advertising. In L. M. Scott, \& R. Batra (Eds.), Persuasive 
Imagery: A Consumer Response Perspective (pp. 267-295). Lawrence Erlbaum.

$\mathrm{Yu}, \mathrm{N}$. (2009). Nonverbal and Multimodal Manifestation of Metaphors and Metonymies: A Case Study. In C. Forceville, \& E. Urios-Aparisi (Eds.), Multimodal Metaphor (pp. 119-143). Mouton de Gruyter.

Zhao, X. F. (2017). Multimodal Construction of Discourse Perspective in Graphic Narrative from the Perspective of Cognitive Poetics. Journal of PLA University of Foreign Languages, 1, 35-43.

Zhao, X. F., \& Li, X. W. (2016). EMOTION Representation Model of Continuum from Metonymy to Metaphor in Narrative Picture Books-From the Perspective of Cognitive Poetics. Foreign Language Education, 1, 10-14. 